\title{
FINANCIAL SECURITY OF MILITARY JUDGES IN SOUTH AFRICA
}

\author{
Aifheli Enos Tshivhase• \\ Nelson Mandela University
}

\begin{abstract}
The status of military courts within the South African judicial system is uncertain. This uncertainty makes it challenging to determine the acceptable degree of their independence, including determining the acceptable basic financial security of military judges. In Van Rooyen $v$ The State (2002) 5 SA 246 (CC), the Constitutional Court accepted a lower standard of independence in relation to magistrates' courts than it requires of the High Courts. It did this primarily because the Constitution provides for a hierarchy of courts and, in its view, this justifies the different degrees of independence of the various courts. This article will report on a systematic investigation into the status of military courts within the South African court hierarchy mainly in comparison with magistrates' courts with the aim of making a recommendation on the appropriate level of remuneration for military judges.
\end{abstract}

\section{Introduction}

Basic financial security of judicial officers is one of the important requirements of judicial independence. In previous research, this author pointed out that the question of financial security of military judges is a complex one and requires special investigation. The uncertainty of the place of military courts within the South African court hierarchy and the uniqueness of these courts make it challenging to determine what constitutes adequate basic financial security for military judges and who should determine it. The key purpose of this article is to reflect on aspects of financial security of military judges. The article attempts to

Scientia Militaria, South African Journal of Military Studies, Vol 45, No. 2, 2017, pp. 81-104. doi : $10.5787 / 45-2-1208$ show that there is considerable room for improvement regarding financial security of military judges, and argues that overall, military judges are not adequately remunerated as required in terms of the principle of basic financial security, which 
in turn raises questions about the judicial independence of military judges from an objective point of view. The article makes a recommendation, among others, on the appropriate level of remuneration for these judges with the view of improving the independence of military courts. It does this by reporting on a systematic investigation into the position of military courts within the South African court hierarchy, mainly in comparison with magistrates' courts, and by considering some foreign trends and possible best practices in this field. The author further argues that military courts compare closely with magistrates' courts.

\section{Application of judicial independence to military courts}

The question of application of the principle of judicial independence to military courts can be addressed at two levels, namely international law $^{1}$ and domestic law, by considering whether the relevant legal frameworks apply to these courts. With regard to the former, it is particularly important because s 199(5) of the Constitution of the Republic of South Africa, 1996 (the Constitution) provides that " $[\mathrm{t}]$ he security services must act ... in accordance with ... customary international law and international agreements binding on the Republic". ${ }^{2}$

A number of international instruments binding on the Republic of South Africa require independent and impartial courts. Almost all of these instruments are in the field of human rights. They link judicial independence with the right to a fair trial. Thus, judicial independence is seen as a prerequisite for the enjoyment of the right to a fair trial. The starting point is the Universal Declaration of Human Rights (UDHR). ${ }^{3}$ Article 10 of the UDHR provides that "[e]veryone is entitled in full equality to a fair and public hearing by an independent and impartial tribunal, in the determination of his [her] rights and obligations and of any criminal charge against him [her]". ${ }^{4}$ Similarly, Art 14(1) of the International Covenant on Civil and

${ }^{1}$ This author addressed this question including some of the weaknesses of international law in this area in a doctoral thesis titled 'Military Courts in a Democratic South Africa: In Search of their Judicial Independence' (University of Cape Town 2012) at 116-133, available at https://open.uct.ac.za/handle/11427/288/browse?value=Tshivhase\%2C+Aifheli+Enos \&type $=$ author.

${ }^{2}$ According to s 199(1) security services include the defence force.

${ }^{3}$ Adopted and proclaimed by United Nations General Assembly Resolution 217 A (III) of 10 December 1948.

${ }^{4}$ The UDHR was adopted as a declaratory instrument not meant to be binding. However, some scholars have argued that "[b]y virtue of its widespread acceptance, the Universal Declaration has gradually assumed an independent status as a statement of customary international law": see Phillip, H 'Human Rights and Economic Policy Discourse: Taking Economic and Social Rights Seriously' (2002) 33 Columbia Law Review at 2. In the terms of the South African Constitution, s 232: "Customary international law is 
Political Rights (ICCPR) provides that "[i]n the determination of any criminal charge against him [her], or of his [her] rights and obligations in a suit of law, everyone shall be entitled to a fair and public hearing by a competent, independent and impartial tribunal established by law". 5

The UN Human Rights Committee (HRC), which monitors the implementation of the ICCPR, has stated that the right to be tried by an independent and impartial tribunal "is an absolute right that may suffer no exception". ${ }^{6}$ Moreover, "[t]he provisions of article 14 apply to all courts and tribunals within the scope of that article whether ordinary or specialized". 7 It is therefore not difficult to conclude that military courts fall within the scope of the relevant articles by virtue of their wide jurisdiction because they have jurisdiction to try both military and criminal offences. ${ }^{8}$

In addition, there are some important expectations from the field of humanitarian law with regard to the independence of military courts. The Geneva Convention (III) Relative to the Treatment of Prisoners of War explicitly requires military courts to be independent and impartial. ${ }^{9}$ This convention applies "to all cases of declared war or of any other armed conflict which may arise between two or more of the High Contracting Parties" and "to all cases of partial or total

law in the Republic unless it is inconsistent with the Constitution". It can hardly be argued that art 10 of the UDHR is inconsistent with the Constitution. South Africa is bound by those aspects of the UDHR that have attained the status of customary international law.

${ }^{5}$ Opened for signature 16 December 1966, 999 UNTS 171 (entered into force 23 May 1976). Another international instrument recognising the principle of judicial independence is the International Convention on the Protection of the Rights of All Migrant Workers and Members of Their Families, opened for signature 18 December 1990, GA res 45/158, Art 18 (entered into force 1 July 2003).

${ }^{6}$ UN Human Rights Committee, Communication No 263/1987, M. Gonzalez del Rio v Peru, UN Doc CCPR/C/46/D/263/1987 (1992), para 5.2.

${ }^{7}$ UN Human Rights Committee, General Comment No 13 (Equality before the courts and the right to a fair and public hearing by an independent court established by law) Twentyfirst session (1984), para 4.

${ }^{8}$ See s 9(2) and 10(1)(a) of the Military Discipline Supplementary Measures Act 16 of 1999 (Military Discipline Act).

${ }^{9}$ Geneva Convention (III) Relative to the Treatment of Prisoners of War, opened for signature 12 August 1949, 75 UNTS 135, Art 84 (entered into force 21 October 1950): This article requires prisoners of war to be tried in a military court that offers essential guarantees of independence and impartiality. It does not stipulate the nature of offences or trial as is the case with the UDHR and the ICCPR. South Africa has ratified this Convention. 
occupation of the territory of a High Contracting Party", ${ }^{10}$ and can only be invoked if one is dealing with prisoners of war or victims of war.

However, the fact that the Prisoners of War Convention specifically requires military courts to be independent in the above circumstances suggests that international humanitarian law generally expects military courts to be independent. If that is not how we should read the Convention, it will be difficult to expect countries to be able to comply with the provisions of Art 84 of the abovementioned Convention because it might be impractical or unrealistic, during an armed conflict, to expect a country, which generally operates non-independent military courts for its citizens, to set up independent military courts all of a sudden in order to satisfy the provisions of Art 84 in relation to prisoners of war or victims of war.

Moving on to the African continent, Art 26 of the African Charter on Human and Peoples' Rights (African Charter) ${ }^{11}$ stipulates that the states parties "shall have the duty to guarantee the independence of the Courts". The African Commission on Human and Peoples' Rights (the African Commission) has dealt with numerous complaints concerning military courts. According to this Commission, courts referred to in Art 26 include military courts. It has noted in a resolution that:

[I]n many African countries military courts and special tribunals exist alongside regular judicial institutions. The purpose of military courts is to determine offences of a pure military nature committed by military personnel. While exercising this function, military courts are required to respect fair trial standards (emphasis added). ${ }^{12}$

The result of all of these binding instruments is that South Africa has an international obligation to ensure that all courts are independent, including military courts. There is no discretion in this regard. Let us now turn to the domestic situation.

Turning to domestic law, s 165(2) of the Constitution declares all courts to be independent. More importantly, section 165(4) of the same Constitution provides that "[o]rgans of state, through legislative and other measures, must assist

\footnotetext{
${ }^{10}$ Art 2.

${ }^{11}$ African Charter on Human and Peoples' Rights, opened for signature 27 June 1981, OAU Doc CAB/LEG/67/3 rev 5 (entered into force 21 October 1986). South Africa has ratified the African Charter.

${ }^{12}$ African Commission on Human and Peoples' Rights, Dakar Declaration and Recommendations Twenty-sixth Session (1999), para 3 in Heyns, C (ed) Human Rights in Africa: Vol 1 (Martinus Nijhoff Publishers 2004) at 586.
} 
and protect the courts to ensure the independence, impartiality, dignity, accessibility and effectiveness of the courts". Again, no discretion has been granted to the state as far as judicial independence of the courts is concerned because the language used in this provision is peremptory and there is nothing to suggest that military courts are excluded from the envisaged assistance and protection by the state to ensure their independence.

\section{The place of military courts within the South African judicial system}

It is important to highlight briefly the place of military courts within the South African judicial system in order to clarify the status of these courts within the system and to demonstrate further that judicial independence applies to military courts. Previous research has shown that military courts are part of the South African judicial system as a matter of domestic law. ${ }^{13}$ Section 166 of the Constitution establishes four types of courts. These are -

(a) "the Constitutional Court;

(b) the Supreme Court of Appeal;

(c) the High Courts, including any high court of appeal that may be established by an Act of Parliament to hear appeals from High Courts;

(d) the Magistrates' Courts..."

Furthermore, s166(e) also speaks of "any other court established or recognised in terms of an Act of Parliament, including any court of a status similar to either the High Courts or the Magistrates' Courts". The table below illustrates the different levels of various courts in order of superiority.

\section{Table A: Levels of courts}

\begin{tabular}{|l|}
\hline The Constitutional Court \\
\hline The Supreme Court Appeal \\
\hline The High Courts or courts of similar status \\
\hline Regional Magistrates' Courts \\
\hline Magistrates' Courts or courts of similar status \\
\hline
\end{tabular}

The Constitutional Court is the highest court of the Republic of South Africa. ${ }^{15}$ It may decide constitutional matters and issues connected with decisions on constitutional matters and any matter, which raises an arguable point of law of

\footnotetext{
${ }^{13}$ See Tshivhase, AE 'Transformation of military courts' (2009) 24 SAPR/PL 450 at 463-5.

${ }^{14}$ These are not mentioned in s 166 of the Constitution. They were created in terms of the Magistrates' Courts Act 32 of 1944.

${ }^{15}$ S 167(3)(a) of the Constitution, 1996.
} 
public importance, which ought to be considered by that court. ${ }^{16}$ On the other hand, the Supreme Court of Appeal may decide only on appeals and issues connected with appeals from the High Courts or courts of similar status, except labour or competition matters. ${ }^{17}$

Section 166(e) envisages a fifth type of court. The courts referred to in s 166 can be divided into two levels - high courts and lower courts. It is not easy to determine where each of the military courts illustrated below falls within the hierarchy of South African courts given the uniqueness and hierarchical nature of military courts.

\section{Table B: Hierarchy of military courts}

\begin{tabular}{|l|}
\hline The Court of Military Appeals \\
\hline The Court of Senior Military Judge \\
\hline The Court of Military Judge \\
\hline Commanding Officers' Disciplinary Hearing ${ }^{18}$ \\
\hline
\end{tabular}

An attempt to determine where each of the above courts falls within the hierarchy of the South African judicial system is crucial when determining suitable measures for structuring the judicial independence of military courts including financial security of military judges because such measures should be informed partially by the status of a particular court and its functions. This is in line with the approach of the Constitutional Court in Van Rooyen v The State ${ }^{19}$ where the Court accepted a lower standard of independence in relation to magistrates' courts than it requires of the High Courts, especially on institutional aspects in relation to the independence of the Magistrates' Commission. The Court did this for several reasons, including the fact that the Constitution provides for a hierarchy of courts and in its view, this justifies the different degrees of independence. This means that the measures that should be adopted to safeguard judicial independence of military courts should be with reference to their status within the courts' hierarchy and their functions.

The determination in this article will focus on the Court of Senior Military Judge (CSMJ) and the Court of Military Judge (CMJ), which can be referred to as

\footnotetext{
${ }^{16} \mathrm{~S} 167(3)(\mathrm{b})(\mathrm{i})$ and (ii) ibid.

${ }^{17} \mathrm{~S} 168(3)$ (a) and (b) ibid.

${ }^{18}$ This forum will not be included in the discussion because its status as a court of law is seriously questionable and requires a separate consideration. For a consideration of the status of this forum generally and its possible future, see Tshivhase, AE 'The future of military summary trials in the modern age' in Duxbury, A \& Groves, M (eds) Military Justice in the Modern Age (Cambridge 2016) at 347.

${ }^{19}$ (2002) 5 SA 246 (CC).
} 
'lower military courts'. The analysis will be court-specific. ${ }^{20}$ The Court of Military Appeals will not be included in the determination because its arrangements warrant a separate discussion. Comparing military courts with courts of similar status within the hierarchy of South African courts may help shed some light on the actual status of these courts. Furthermore, military courts are compared with magistrates' courts because the overall judicial scheme provided for in the Constitution points in this direction. ${ }^{21}$

\section{Comparing lower military courts with magistrates' courts}

The jurisdiction of lower military courts suggests that magistrates' courts provide a suitable basis of comparison for purposes of determining the appropriate measures to ensure financial security of military judges. In this section, the CMJ is compared with district magistrates' courts while the CSMJ is compared with regional magistrates' courts. However, the Constitution does not draw a distinction between magistrates' courts and regional magistrates' courts - such distinction is a creature of statute. As far as judicial independence is concerned, the distinction between the two courts only affects one element - financial security of the respective judicial officers. Regional magistrates naturally earn more than district magistrates. ${ }^{22}$ For purposes of this article, the distinction may prove to be helpful in determining appropriate remuneration for both military judges and senior military judges.

Table C shows how the CMJs compare with district magistrates' courts in terms of jurisdiction in respect of persons, offences and sentencing powers. The first row shows that the expectations with regard to the qualifications of both military judges and district magistrates are almost on a par. The key requirement that separates the two is that military judges must also be qualified military law officers. This entails successful completion of three military courses: basic military training, officers' formative course, and advanced military law course. Taken together, these courses take almost a year to complete depending on the arm of service to which a particular military judge belongs. The second row of the table

\footnotetext{
${ }^{20}$ The Court of a Senior Military Judge is not necessarily a higher court in the greater scheme of things because it has no appellate powers.

${ }^{21}$ Both military and magistrates' courts have jurisdiction to try criminal offences in general.

${ }^{22}$ See Proclamation 327 of 17 March 2016 made in terms of the Magistrates' Act 90 of 1993 for salaries of different grades of magistrates at the time of writing.
} 
suggests that magistrates' courts deal with more people than the CMJ. South Africa's total population is estimated at 56,52 million. ${ }^{23}$

\section{Table C: Comparison between district magistrates' courts and a court of military judge}

\begin{tabular}{|c|c|c|}
\hline & $\begin{array}{l}\text { DISTRICT } \\
\text { MAGISTRATES' } \\
\text { COURTS }\end{array}$ & $\begin{array}{c}\text { COURT OF A MILITARY } \\
\text { JUDGE }\end{array}$ \\
\hline $\begin{array}{l}\text { Qualifications and } \\
\text { experience } \\
\text { required of } \\
\text { presiding officer }\end{array}$ & $\begin{array}{l}\text { Has to be a fit and proper } \\
\text { person; legally qualified; } \\
\text { successful completion of } \\
\text { an applicable course; } \\
\text { must have acted as a } \\
\text { judicial officer for a } \\
\text { substantive period of six } \\
\text { months }^{24}\end{array}$ & $\begin{array}{l}\text { Should have a degree in law, } \\
\text { military law course, rank of major } \\
\text { or equivalent, be a fit and proper } \\
\text { person of sound character, three } \\
\text { years' experience as a practising } \\
\text { advocate or attorney or three } \\
\text { years' experience in the } \\
\text { administration of criminal or } \\
\text { military justice }\end{array}$ \\
\hline $\begin{array}{l}\text { Jurisdiction in } \\
\text { respect of persons } \\
\text { (only criminal } \\
\text { jurisdiction is } \\
\text { considered here) }\end{array}$ & $\begin{array}{l}\text { All persons within the } \\
\text { area of court's } \\
\text { jurisdiction in the } \\
\text { Republic of South Africa }\end{array}$ & $\begin{array}{l}\text { Only persons subject to the } \\
\text { military discipline code (but only } \\
\text { up to the rank of major or } \\
\text { equivalent) within or beyond } \\
\text { South African borders }\end{array}$ \\
\hline $\begin{array}{l}\text { Jurisdiction in } \\
\text { respect of offences }\end{array}$ & $\begin{array}{l}\text { All offences }{ }^{25} \text { except } \\
\text { treason, murder, rape and } \\
\text { compelled rape }\end{array}$ & $\begin{array}{l}\text { All offences (both military and } \\
\text { civilian) except murder, treason, } \\
\text { rape, culpable homicide, or any } \\
\text { offence under ss } 4 \text { and } 5 \text { of the } \\
\text { Military Discipline Code (MDC) }\end{array}$ \\
\hline $\begin{array}{l}\text { Limits in respect of } \\
\text { a sentence of } \\
\text { imprisonment }\end{array}$ & $\begin{array}{l}\text { Imprisonment for a } \\
\text { period not exceeding } \\
\text { three years }\end{array}$ & Maximum is two years \\
\hline $\begin{array}{l}\text { Limits in respect of } \\
\text { a fine }\end{array}$ & Maximum of R100 000 & Maximum of R6 000 \\
\hline $\begin{array}{l}\text { Extra-territorial } \\
\text { jurisdiction and } \\
\text { sittings }\end{array}$ & No & Yes \\
\hline
\end{tabular}

${ }^{23}$ Statistics South Africa Mid-year Population Estimates (July 2017), available at http://www.statssa.gov.za/publications/P0302/P03022017.pdf.

${ }^{24}$ These requirements are in terms of s 10 of the Magistrates' Courts Act 32 of 1944 and General Regulations (GNR. 361 of 11 March 1994) enacted in terms of the Magistrates Act 90 of 1993 (Regulation 3).

${ }^{25}$ Both civilian and military offences, but nothing much should be read into this because civilian courts can try military offences only on paper, as they do not do so in practice.

${ }^{26}$ Offences endangering the safety of forces and offences in relation to conduct in action. These two offences carry sentences of 30 and 10 years, respectively. 
This should be contrasted with the total size of the strength of the South African National Defence Force (SANDF) with a reported membership of 66821 for the period 2015-2016. ${ }^{27}$ The second row shows that magistrates' courts try more offences than CMJs. The offence that separates the two is culpable homicide. Magistrates' courts can try this offence while the CMJ cannot. Similarly, the fourth row shows that magistrates' courts have more sentencing powers in respect of imprisonment than those possessed by a CMJ. Finally, the fifth row suggests that magistrates' courts can impose a far more severe fine than the CMJ. ${ }^{28}$

There is no doubt that magistrates' courts have more powers than the CMJ. However, the CMJ is unique in three senses. First, it tries both military and civilian offences as a matter of law and practice. Second, it has extra-territorial jurisdiction. Third, it may at times be required to operate in a war or warlike environment, such as peace support operations. These aspects present a mixed picture of how magistrates' courts compare with the CMJ for purposes of determining the level of protection, which should be afforded the CMJ to ensure its independence. Nonetheless, the CMJ compares very closely with magistrates' courts.

Let us now consider the position of the CSMJ in relation to that of regional magistrates' courts. The table below illustrates how the two compare. The first row shows that military legislation is much clearer compared to legislation governing magistrates regarding the requirements for appointment of military judges. However, most of the requirements in the CSMJ column are considerations in the appointment of regional magistrates, i.e. experience in the administration of justice. There are two unique requirements for appointment as a senior military judge. One is that a candidate must also be a qualified military officer, which requires completion of certain military courses as already explained in respect of ordinary military judges. The other is that one must be a qualified military legal practitioner by virtue of having passed a departmental course in military law. This suggests that more is expected of senior military judges compared to regional magistrates in

\footnotetext{
${ }^{27}$ Department of Defence, Annual Report (2015/16) http://www.dod.mil.za/documents/annualreports/Annual\%20Report\%202016\%20RG B\%20Final\%20to\%20DoDsmall.pdf at 122]

${ }^{28}$ However, this does not represent the total picture because the maximum fine of R6 000 , which may be imposed by the CMJ, is subject to a maximum penalty imposed by law for a particular offence and its own penal jurisdiction. It means that there could be instances where the CMJ would be empowered to impose a fine over R6 000, provided the offence in question requires such and the maximum imprisonment for that offence does not exceed the penal jurisdiction of a CMJ. For example, if a particular offence provides for a period of imprisonment not exceeding three years with an alternative of imposing a fine not exceeding R7 000, the CMJ would not have jurisdiction to try the offence in question because the maximum period of imprisonment for that offence exceeds its penal jurisdiction.
} 
terms of qualifications and this must be viewed in the context within which military judges function.

Table D: Comparison between the CSMJ and regional magistrates' courts

\begin{tabular}{|c|c|c|}
\hline & $\begin{array}{c}\text { REGIONAL } \\
\text { MAGISTRATES' COURTS }\end{array}$ & $\begin{array}{l}\text { COURT OF SENIOR } \\
\text { MILITARY JUDGE }\end{array}$ \\
\hline $\begin{array}{l}\text { Qualifications } \\
\text { and } \\
\text { experience } \\
\text { required of } \\
\text { presiding } \\
\text { officer }\end{array}$ & $\begin{array}{l}\text { Magistrate or LLB or a pass } \\
\text { in the Public Service Senior } \\
\text { Law Examination or } \\
\text { equivalent or superior and } \\
\text { recommended as suitable for } \\
\text { appointment by the } \\
\text { Magistrate's Commission }\end{array}$ & $\begin{array}{l}\text { Degree in law, military law course, } \\
\text { rank of colonel or equivalent, be a } \\
\text { fit and proper person of sound } \\
\text { character, five years' experience as } \\
\text { a practising advocate or attorney or } \\
\text { five years' experience in the } \\
\text { administration of criminal or } \\
\text { military justice }\end{array}$ \\
\hline $\begin{array}{l}\text { Jurisdiction } \\
\text { in respect of } \\
\text { persons } \\
\text { (criminal } \\
\text { jurisdiction } \\
\text { only) } \\
\end{array}$ & $\begin{array}{l}\text { All persons within the area of } \\
\text { court's jurisdiction in the } \\
\text { Republic of South Africa }\end{array}$ & Any person subject to the MDC \\
\hline $\begin{array}{l}\text { Jurisdiction } \\
\text { in respect of } \\
\text { offences }\end{array}$ & All offences except treason & $\begin{array}{l}\text { Any offence other than murder, } \\
\text { treason, rape or compelled rape } \\
\text { and culpable homicide committed } \\
\text { within the Republic of South } \\
\text { Africa }\end{array}$ \\
\hline $\begin{array}{l}\text { Limits in } \\
\text { respect of a } \\
\text { sentence of } \\
\text { imprisonment }\end{array}$ & No limit & No limit \\
\hline $\begin{array}{l}\text { Limits in } \\
\text { respect of a } \\
\text { fine }\end{array}$ & Maximum of R300 000 & $\begin{array}{l}\text { Maximum of R6 } 000 \text { but subject to } \\
\text { the maximum fine provided by law } \\
\text { for a particular offence }\end{array}$ \\
\hline $\begin{array}{l}\text { Extra- } \\
\text { territorial } \\
\text { jurisdiction } \\
\text { and sittings }\end{array}$ & No & Yes \\
\hline
\end{tabular}

As was the case in Table $\mathrm{C}$, the second row shows that regional magistrates' courts in all likelihood try more people than the CSMJ because the civilian population will usually be far greater than persons subject to the MDC in any given area. The same logic applies in respect of the third row, namely that regional magistrates' courts try more serious offences than the CSMJ. The CSMJ only has a chance to try more offences when such offences have been committed beyond the borders of the Republic of South Africa. It is common cause that this rarely happens because it largely depends on the extent to which members of the defence force are deployed outside the borders of South Africa. 
The fourth row shows that regional magistrates' courts and the CSMJ have the same sentencing powers with respect to imprisonment. However, this is slightly misleading because the extensive powers of the CSMJ with respect to imprisonment are rarely exercised. The reason for this is that the CSMJ does not have jurisdiction to try most serious offences ${ }^{29}$ (committed within the Republic of South Africa) that would attract a sentence of severe imprisonment. This means that despite the enormous powers of the CSMJ to hand down severe sentences, which may include life imprisonment, in practice, regional magistrates' courts still hand down more severe sentences of imprisonment than the CSMJ. Nevertheless, the fact that the extensive sentencing powers of the CSMJ are infrequently exercised does not necessarily mean that such powers must be downplayed when considering the status that should be accorded to the CSMJ. The infrequency does not change the fact that the court possesses such powers. On the whole, the comparison between regional magistrates' courts and the CSMJ also presents a mixed picture. Regional magistrates' courts are stronger in some aspects while the CSMJ is in other aspects. Ultimately, the two could be regarded on a par.

In Canada, a special committee was appointed to consider the compensation of military judges. ${ }^{30}$ One of the crucial issues the committee had to deal with was to determine "the appropriate level of Military Judges' compensation taking into account the nature of their role and the tasks they undertake". ${ }^{31}$ The committee compared the role of military judges to that of other judicial officers in Canada and recommended that Provincial Court judges across Canada provide an appropriate basis of comparison for purposes of determining the appropriate level of compensation. ${ }^{32}$ Provincial Court judges are largely the equivalent of magistrates in South Africa. By way of analogy, the outcome of the Canadian study may serve to indicate that comparing military courts with magistrates' courts is generally appropriate. ${ }^{33}$

\footnotetext{
${ }^{29}$ These are murder, culpable homicide, rape and compelled rape. All these offences are generally common within the Republic of South Africa.

${ }^{30}$ Department of National Defence 'Report on the Compensation of Military Judges' (2004), available at www.forces.gc.ca/site/reports/mjcc04/index e.asp.

${ }^{31}$ Ibid.

${ }^{32}$ It is important to note that another member of the Committee, L'Heureux-Dube J, disagreed with the majority and took the view that military judges should be granted a status equivalent to that of Canadian Superior Court judges.

${ }^{33}$ For some related developments in Canada, see Department of National Defence, 'Report on the Compensation of Military Judges' (2008), available at www.forces.gc.ca/site/reports-rapports/mjcc08/index-eng.asp . This report builds on the studies carried out in the preceding years. It makes recommendations on the remuneration of military judges, taking into account a number of new factors that arose since the previous studies. These are dealt with below.
} 
Canada stands out as a country that has probably done the most studies in the area of trying to understand the place of military courts within the hierarchy of a judicial system. In addition, it is also an important jurisdiction to consider for the following reasons:

- It is on the cutting edge of reform of military justice in the world;

- The current system of military justice in South Africa was modelled on the Canadian system as it existed then (i.e. in 1999); and

- Canadian jurisprudence has been very influential in shaping South

Africa's Constitutional Court jurisprudence in the field of judicial independence as seen in the judgment such as De Lange $v$ Smuts. ${ }^{34}$

It is therefore appropriate to consider Canada for comparative purposes in this area. However, Canada is not the only country worth considering. Some of the countries that have also been on the cutting edge of reform of military courts considered in this article are Australia, India, the United Kingdom (UK) and New Zealand. ${ }^{35}$ Lessons can be drawn from these jurisdictions as well. Moreover, armed forces in most democracies share common features and concerns, and do learn from each other in various fields. There may be other jurisdictions worth considering over and above these in this field but the scope of this article did not permit such an investigation. However, this does not mean the solution to the problems faced has to be the same across all jurisdictions. It is a matter of drawing lessons from other jurisdictions that have dealt with similar challenges in this fast developing area of law in some jurisdictions. In considering these countries, the intention of the study on which this article reports was not to make a comprehensive comparative study of South Africa and the countries considered but rather to establish possible trends in some areas and also to refer to what this author regards as some of the best practices from these jurisdictions on the subject of financial security of military judges.

\section{Addressing aspects of financial security of military judges}

This section addresses the financial security of military judges through a series of questions. These are: Who should determine the remuneration of military

\footnotetext{
${ }^{34} 1998$ (3) SA 785 (CC).

${ }^{35}$ In New Zealand, military judges are civilians. However, this author does not attach significance to this in relation to financial security, as all judicial officers should enjoy basic financial security regardless of the court in which they function. Whether or not military judges should be civilians is a different topic and one which this author has commented on in previous research.
} 
judges? Which factors should guide the remuneration of military judges? What is the appropriate level of remuneration of military judges?

Who should determine the remuneration of military judges?

In the current setup, military judges are public servants. ${ }^{36}$ Prior to 2004 , the salaries of soldiers, including military judges, were determined in accordance with the Public Service Act, No 103 of 1994. This situation has been altered by the Defence Act of 2002. ${ }^{37}$ Salaries of military personnel are now determined by the Military Bargaining Council (MBC), failing which, by the Minister of Defence taking into account recommendations of the recently established Defence Force Commission but with the approval of the Minister of Finance. ${ }^{38}$ In the recent past, the MBC has failed to resolve many of the disputes between the SANDF and the military trade unions concerning transformation and conditions of service of soldiers. Some of the matters ended in the Constitutional Court, and soldiers have engaged in industrial action. ${ }^{39}$

Although the extent to which the above scenario has affected military judges is unclear, it is inconsistent with judicial independence for military judges to be caught up in the situation described above. ${ }^{40}$ The remuneration arrangement described above is not suitable for judicial officers. It ignores the status of military judges as judicial officers and this is inconsistent with the United Nations Basic Principles on the Independence of Judiciary (UN Principles), ${ }^{41}$ which require that

\footnotetext{
${ }^{36}$ See Public Service Act, 1994 (Proclamation No 103 of 1994), s 8 read with the definition of 'employee' in s 1 of the Act and also s 5(b) of the Defence Act 42 of 2002 which place the Department of Defence within the public service.

${ }^{37}$ Defence Act 42 of 2002 (Defence Act). However, the SANDF is still part of the public service although the conditions of service of military personnel are now extensively regulated by the new Defence Act.

${ }^{38}$ Defence Act, s 55. The Defence Force Commission deals with conditions of service of all military personnel.

${ }^{39}$ See SANDU v Minister of Defence and Others 2007 (5) SA 400 for an account of some of the events on this issue.

${ }^{40}$ See Van Rooyen $v$ The State (n 19) para 139 for remarks that support this view.

${ }^{41}$ Adopted by the Seventh United Nations Congress on the Prevention and the Treatment of Offenders held in Milan from 26 August to 6 September 1985 and endorsed by GA Res 40/32 and 40/146 of 13 December 1985. These principles have been cited with approval by the Constitutional Court in a number of judgements, including in the Justice Alliance of South Africa $v$ President of the Republic of South Africa \& others 2011 (5) SA 388 (CC) para 38. According to the Preamble of the Principles, they are formulated to assist member states in their task of securing and promoting the independence of the judiciary and "should be taken into account and respected by the Governments within the framework of their national legislation and practice...". The African Commission has referred to these principles on numerous occasions to justify their conclusions on the violation of the right to fair trial in the African Charter.
} 
the law should secure adequate remuneration and conditions of service for judicial officers. ${ }^{42}$ Section 165 of the Constitution read with the UN Principles on Judicial Independence presupposes the adoption of special measures, which ensure basic financial security for judicial officers. In Van Rooyen $v$ The State, the Constitutional Court held that salaries of magistrates must be determined in accordance with s 165 of the Constitution and that the power to determine such salaries is subject to constitutional control. ${ }^{43}$ There is no justification why this should be different for military judges.

Furthermore, the Constitutional Court has stated that judicial independence is a principle and a norm that went beyond and lay outside of the Bill of Rights and therefore is not subject to the limitation clause. ${ }^{44}$ This means that non-compliance with the basic conditions of judicial independence cannot be justified. Measures must be adopted to address financial security of military judges in such a way that their financial packages are appropriately determined and adequate.

The compensation of magistrates and civilian judges is maintained by an independent structure - the Independent Commission for the Remuneration of Public Office Bearers ${ }^{45}$ established in terms of s 219 of the Constitution and the Independent Commission for the Remuneration of Public Office Bearers Act. ${ }^{46}$ Although s 219 does not mention magistrates as public office bearers, s 1 of the legislation establishing the Commission includes magistrates in the definition of public office bearers. ${ }^{47}$ Let us look at how some countries on the cutting edge of development of military justice have dealt with the question of remuneration of their military judges.

In Australia, the remuneration of military judges used to be set by the Commonwealth Remuneration Tribunal when the new system was still up and running. ${ }^{48}$ In the proposed system, the position has not changed. ${ }^{49}$ That move

Another declaratory document adopted recently is the Bangalore Principles of Judicial Conduct. It was adopted by the Judicial Group on Strengthening Judicial Integrity in November 2002. The author should also point out that, apart from these two, there are numerous documents on judicial independence (for a brief indication, see The Judicial Institution in Southern Africa (Siber Ink 2006) at 1-13.

${ }^{42}$ Ibid.

${ }^{43}$ Van Rooyen $v$ The State op cit para 148.

${ }^{44}$ Ibid para 35.

${ }^{45}$ The Commission consists of seven members appointed by the President in terms of s 3 of the Act. At the time of writing, the chairperson of the Commission was Judge CJ Musi.

4692 of 1997.

${ }^{47}$ The original version of the Act did not include magistrates as public office bearers, but was later amended to include them.

${ }^{48}$ That is the same structure that determines remuneration for justices in Chapter III courts in that country. 
amounted to integration of military judges into the mainstream on the question of remuneration. Salaries and allowances of judge advocates in the United Kingdom are determined by the Lord Chancellor ${ }^{50}$ with the approval of the Treasury. ${ }^{51}$ In Canada, the remuneration of military judges is regularly reviewed by a Compensation Committee. ${ }^{52}$ New Zealand has passed legislation, which requires the salaries of military judges to be paid out of public money at a rate determined by the Remuneration Authority. ${ }^{53}$ The same institution determines salaries of other judges in New Zealand. This, too, is an integration of military judges into the mainstream regarding their remuneration. On the issue of reduction of salaries, of the five countries examined, New Zealand and India are the only countries with legislative provisions which specifically bar the reduction of salaries of military judges. ${ }^{54}$

The above survey shows an emerging trend to establish special measures to deal with financial security of military judges, a move which augurs well for judicial independence of these judges. Military judges are increasingly receiving special attention. The majority of countries surveyed seemed to favour integrating military judges into existing mainstream structures with respect to the determination of their salaries. Of all the countries considered, Canada was the only country with a structure created specifically to look into the compensation of military judges.

As already indicated, the law envisages special measures regarding the remuneration of all judicial officers. In my view, there are three possible options that could be followed on who should determine the remuneration of military judges.

The first option could be to integrate military judges into mainstream civilian structures on the issue of remuneration. They could be included in the work of the Independent Commission for the Remuneration of Public Office Bearers. This would obviously require amending the definition of a public office bearer in s 3 of the Independent Commission for the Remuneration of Public Office Bearers Act to include military judges as was done in the case of magistrates. Military judges are judicial officers, There should therefore not be any legal

\footnotetext{
${ }^{49}$ See s 20 of the Military Court of Australia Bill.

${ }^{50}$ The Lord Chancellor is a senior functionary in Great Britain responsible for the efficient functioning and independence of the courts.

${ }^{51} \mathrm{~S} 33$ of Courts-Martial (Appeals) Act 1951.

${ }^{52}$ S 165.22(2) of the National Defence Act 1985.

${ }^{53}$ Established in terms of the Remuneration Authority Act 1977.

${ }^{54}$ See s 20(3) of the Court Martial Act 2007 and s 10 of The Armed Forces Tribunal Act 2007, respectively.
} 
difficulty in accepting them as public office bearers. Integrating military judges into mainstream civilian structures is supported by foreign trends in the area of compensation of military judges as seen in Australia and New Zealand. Over the years, the Commission on the Remuneration of Public Office Bearers has developed expertise in determining salaries of judicial officers. This move might help in lifting the status of military judges and the strengthening of their financial security. However, a possible difficulty with this option is that military judges and their work are hardly known in civilian settings due to the historical separate existence of the military justice system. The Commission will need to study the role of military judges and their unique situation in order to come up with appropriate recommendations with respect to their compensation. This is not an impossible task although it may initially require a considerable effort. It is hoped that the work done and reported in this article could assist in that process.

The second option could be the Defence Force Service Commission. ${ }^{55}$ The role of the Commission is to make recommendations to the Minister of Defence and Military Veterans concerning the salaries, service benefits and other conditions of service of members of the Defence Force annually. The Commission is empowered to conduct research on the conditions of service and to consider any representations made to it.

Ordinarily, the Commission looks into the salaries of military law officers, and by extension military judges, but it is unlikely to address the issues concerning military judges if it looks at them as mere military law officers instead of viewing them as judicial officers. Nevertheless, there are two concerns which suggest that the Commission may not be a suitable vehicle to deal with the financial security of military judges. The first is that the Commission would, in all likelihood, be overwhelmed in its work given the size of the Defence Force and the diverse interests of its members. It can be expected that the financial security of military judges would be over-shadowed by many other competing interests. The second concern is the independence of the Commission and the force of its recommendations. The Commission consists of no fewer than eight members all of whom are appointed by the Minister of Defence. Its recommendations must be approved by the Minister of Defence acting in consultation with the Minister of Finance, and agreed upon in the MBC. ${ }^{56}$ If no agreement can be reached in the $\mathrm{MBC}$, the Minister "may, after consideration of any advisory report by the Military Arbitration Board and with the approval of the Minister of Finance, determine the

\footnotetext{
${ }^{55}$ Established through the Defence Amendment Act 22 of 2010, amending s 55 of the Defence Act 2002.

${ }^{56}$ S 5(1) of the Defence Amendment Act 2010.
} 
pay, salaries and entitlements ..." of members of the Defence Force. ${ }^{57}$ The inappropriateness of the $\mathrm{MBC}$ as a vehicle to determine salaries of military judges has already been pointed out and will not be repeated here. Furthermore, it is clear that the force of the recommendations of the Commission is weak, as it is entirely dependent on the take of the Minister of Defence in the first place, and the Minister of Finance in the second place.

The third and probably the most viable option to determine the remuneration of military judges could be the creation of an independent structure, which could be styled as the Military Judicial Commission. ${ }^{58}$ This option is also supported by foreign precedents as shown in the context of Canada above. The Commission could be modelled on the South African Magistrates' Commission. ${ }^{59}$ It would be more useful if the Commission is also empowered, by law, to conduct research on the working conditions of military judges and to make policy recommendations. Most importantly, the annual recommendations of the Commission concerning the remuneration of military judges should be submitted to Parliament for approval, not to the Minister of Defence, as this may mean that military judges would be at the mercy of the Executive regarding their remuneration. The implication is that military judges would have to be paid from monies appropriated by Parliament instead of the coffers of the Department of Defence. ${ }^{60}$ The Military Judicial Commission could serve as a filter between the military judiciary and the SANDF or Parliament with regard to remuneration of military judges and that would enhance the independence and dignity of military courts. ${ }^{61}$ It is possible to structure such a body in a way that it would not cost much to the state.

${ }^{57} \mathrm{~S} 55(3)$ of the Defence Act.

${ }^{58}$ See also Tshivhase, AE 'Institutionalising a Military Judicial Office and Improving Security of Tenure of Military Judges in South Africa' Law, Democracy \& Development (2015) 19 (79) at 92, where this author supports this idea in the context of appointment of military judges.

${ }^{59}$ See Tshivhase (n 13 above). In this connection, the Magistrates' Act, 90 of 1993 s 12(1)(a) allows the Minister of Justice to determine salaries in consultation with the Commission. The relationship between this and recommendations made by the Commission for Public Office Bearers is not entirely clear.

${ }^{60}$ Similarly, the recommendations of the Independent Commission on the Remuneration of Public Office Bearers must be submitted to Parliament before their publication in the Government Gazette (see s 8(5) of the relevant Act). This is in line with the UN Principles, which require that the law should secure adequate remuneration of judicial officers. This presupposes the involvement of the legislature in setting the salaries of judicial officers.

${ }^{61}$ Tshivhase (n 13 above) at 473. By way of emphasis, in Reference re: Public Sector Pay Reduction Act (PEI), Attorney General of Canada et al, Interveners; Reference re: Independence of Judges of Provincial Court, Prince Edward Island, Provincial Court 
Finally, encouragement to carry out the above suggestions should be drawn from the fact that military judges are judicial officers and therefore public office bearers. Their uniqueness should not overshadow their actual status.

Which factors should guide the remuneration of military judges?

Section 165 of the Constitution does not explain how to determine appropriate levels of remuneration of judicial officers. The Constitutional Court has acknowledged this to be a difficult area for which there are no easy answers. ${ }^{62}$ What is known is that the remuneration must be adequate, and the UN Principles require that the law should secure adequate remuneration of judicial officers. It is also known that there is currently no military judicial salary, in other words, military judges are not recognised as judicial officers for purposes of remuneration.

The Independent Commission for the Remuneration of Public Office Bearers is required to take the following factors into account when determining appropriate salary levels for different office bearers including judicial officers:

When making recommendations ...the Commission must take the following factors into account:

i. The role, status, duties, functions and responsibilities of the office bearers concerned;

ii. The affordability of different levels of remuneration of public office bearers;

iii. Current principles and levels of remuneration, particularly in respect of organs of state, and in society generally;

iv. Inflationary increases;

v. The available resources of the state; and

vi. Any other factor which, in the opinion of the said Commission, is relevant. ${ }^{63}$

Act and Public Sector Pay Reduction Act; Attorney General of Canada et al, Interveners (1997) 150 DLR $\left(4^{\text {th }}\right) 577$ the Canadian Supreme Court held that "independent commissions were required to improve the process designed to ensure judicial independence but that the commissions' recommendations need not be binding. These commissions were intended to remove the amount of judges' remuneration from the political sphere and to avoid confrontation between governments and the judiciary...". However, it must be noted that in In re: Certification of the Constitution of the Republic of South Africa 1996 (4) SA 744 (CC), paras 59 and 124, it was held that there is no obligation to establish independent structures to serve as a filter between the judiciary and the executive, and that this is a matter of political choice, not mandatory for securing judicial independence. On the other hand, the Constitutional Court recognises that such structures play a crucial role in the determination of salaries and conditions of service for judicial officers: Van Rooyen $v$ The State op cit paras 145-148.

${ }^{62}$ Van Rooyen $v$ The State op cit para 138.

${ }^{63} \mathrm{~S} 8(6)$ of the Independent Commission for the Remuneration of Public Office-bearers Act 92 of 1997. 
The above factors are quite interesting because they are comprehensive, capable of flexible application to various office bearers, and would in all likelihood ensure that salaries of judicial officers are adequate if applied reasonably. Factor $i$ is the crucial missing link with regard to the remuneration of military judges, as their role, status, duties, functions and responsibilities as judicial officers are currently not taken into account. Factors ii-v are generic, and are usually considered in the ordinary course of events.

Switching to comparative analysis on the issue, Canada has evolved to become a model in structuring the remuneration of military judges. As already pointed out, Canada has established a special and independent committee whose purpose is to enquire into the adequacy of the remuneration of military judges as suggested already. ${ }^{64}$ The committee has conducted studies and compiled reports on the issue. In its enquiries, the committee must be guided by the following factors:

a. The prevailing economic conditions in Canada, including the cost of living and the overall economic and current financial position of the federal government;

b. The role of financial security of military judges in ensuring judicial independence;

c. The need to attract outstanding officers as military judges; and

d. Any other objective criteria that the Commission considers relevant. ${ }^{65}$

Each of these factors is discussed by the Military Judges Compensation Committee in its 2008 Report. Countries that are keen to improve and understand the financial security of military judges could find the work being carried out in Canada to be instructive. Factor b is very important because it goes to the heart of the issue. The role of the committee is to determine an appropriate level of remuneration of military judges based on the above factors. ${ }^{66}$ Its aim is neither to determine the minimum remuneration nor to achieve maximal conditions. ${ }^{67}$ Having assessed the factors provided for in the Remuneration of Public Office Bearers Act and the Canadian approach to the matter, it is proposed that the appropriate remuneration of South African military judges should be guided by the following six factors:

\footnotetext{
${ }^{64}$ The Military Judges Compensation Committee.

${ }^{65}$ See Department of National Defence, Report of the Military Judges Compensation Committee (2008) www.forces.gc.ca/site/reports-rapports/mjcc08/index-eng.asp.

${ }^{66}$ See ibid at 6-7. For the workings of the Committee, see art. 204.23 to 204.27 of the Queens ${ }^{67}$ See ibid. Regulations and Orders.
} 
- the role, status, duties, functions and responsibilities of military judges including their unique circumstances; ${ }^{6}$

- the status of military courts within the South African judicial system;

- the role of financial security of military judges in ensuring judicial independence;

- the available resources of the state taking into account the prevailing economic conditions;

- inflation; and

- the need to attract outstanding officers as military judges.

These factors could go a long way in determining an appropriate level of remuneration of military judges.

\section{What is the appropriate level of remuneration of military judges?}

It is probably ambitious to attempt to answer this question within the scope of this article. Bearing that difficulty in mind, what follows is an attempt to answer the question in a principled and tentative way, without necessarily considering all the pragmatic aspects of the question but primarily being guided by the factors proposed above.

It has already been established that, unlike in the case of High Court judges and magistrates, there is no special dispensation for determining salaries and benefits for military judges. As will be discussed further below, these judges are not adequately remunerated except those who have been in service for a very long time who receive better remuneration on that basis and consistent 'good' performance. This can be discerned from the Occupation Specific Dispensation for Military Law Practitioners (OSD MLP) adopted in 2009 and the Personnel Management Code (PMC) adopted in 2010. ${ }^{69}$

According to the OSD MLP, the PMC and salary grades for the 2016 financial year, a military judge with legal experience of between three (minimum required) and ten years' experience earned between R266 $193^{70}$ (ML-2) and R434 142 (ML-3) per annum depending on the exact number of years of service

${ }^{68}$ The assessment of this factor should also include the fact that military judges are required to travel extensively, sometimes even beyond the borders of the Republic of South Africa.

${ }^{69}$ Established in terms of the Defence Act and on file with the author.

${ }^{70}$ At this level, the package is not all-inclusive, meaning that it excludes benefits such as medical aid and housing allowance. These are difficult to quantify, suffice to say that the military offers the most generous medical benefits than any state department. The 2016 housing allowance for public servants varied between R900 and R1 200 per month, depending on whether the employee was renting or not. 
and experience, qualifications and performance. In contrast, an entry-level magistrate earns R835 444. ${ }^{71}$ Theoretically, this means that an entry-level magistrate could be earning two times more than an entry-level military judge depending on the experience of the military judge in question. As already argued, magistrates provide an appropriate comparator for military judges. To illustrate another possible scenario, a senior military judge with legal experience of between 11 and 14 years earns between R612 744 and R743 604 (ML-4) per annum (allinclusive package) in comparison with the total remuneration package of R918 891 earned by a senior magistrate. ${ }^{72}$ The salaries of military judges begin to compare very closely with those of magistrates in a situation where military judges have experience of between 16 and 30 years. Military judges in the latter category earn between R707 922 (minimum of ML-5) and R1 284186 (maximum of ML-6). The author has not been able to establish how many of the twenty military judges are in the latter category at present (i.e. at the end of 2017). That said, even if there were to be a number of military judges in the higher remuneration bracket, the fact remains, that the current system does not guarantee adequate remuneration of all military judges. Adequate remuneration of judicial officers must be guaranteed and should not be left to chance.

The remuneration of military judges described above is, in the view of this author, inadequate at lower to middle level (from three to ten years of experience). ${ }^{73}$ This is glaringly lower when compared with judicial officers of similar status in the civilian setting. In my view, the remuneration packages of magistrates could be seen as the national norm in terms of what judicial officers

${ }^{71}$ See Proclamation No 327 of 17 March 2016 made in terms of s 12(1) the Magistrates' Act 90 of 1993 . This amount is a total remuneration package, in other words, there are no benefits over and above that amount. The accuracy of the figures presented here may be disputed given the varied nature of the application of the OSD MLP and the PMC in relation to specific individuals. However, the range is generally accurate in terms of the OSD MLP and the PMC on file with the author.

72 Ibid.

${ }^{73}$ Compare, however, the view by Nel, M Sentencing Practice in Military Courts (unpublished LLD thesis, Unisa 2012) at 202 that "the salaries and benefits of military judges are sufficiently protected and governed by legislation and policy documents" (emphasis added), available at http://uir.unisa.ac.za/bitstream/handle/10500/5969/dissertation_nel_m.pdf?sequence= 1. While one accepts that there is legislation and policy dealing with salaries of military law officers in general, Nel does not pay sufficient attention to the 'adequacy' of remuneration as one of the crucial elements of financial security as stated by the Constitutional Court in Van Rooyen v The State op cit para 138. Nel compares military law officers with other ordinary military officers in the SANDF. Military judges should be compared with their peers in the civilian setting to ensure appropriate recognition of their status as judicial officers. 
who occupy courts of similar status should earn, especially taking into account the considerations that are made in terms of legislation when making such determinations by the relevant structure. To compound the problem, military judges also do not enjoy security of tenure. The relevant legislation does not guarantee a period of appointment. It is common knowledge that, in the recent past, the appointment of military judges has ranged between one year (sometimes less) and two years. In some cases, appointments are renewed and in other cases, they are not or delayed significantly. In fact, at some point between 2015 and 2016 some judges were not functioning for over a year because the Minister of Defence delayed renewing appointments of military judges. In one case, a military judge (Lt Col. O'Brien) raised serious concerns in a court judgment about the lack of tenure and how this could affect the independence of military judges. The following passage by the judge in question is instructive and worth reproducing:

An aspect that the Court raised in respect of its concerns regarding the constitutionality of the assignment of military judges was the delay in the assignment of Military Judges in general (including that of the Military Judge) in these particular cases. The fact that for a period of 15 months (01 April 2015-30 May 2016), the Military Judge was not assigned could have a bearing on the outcome of whether there had been an unreasonable delay in the proceedings in terms of sec 342A CPA [Criminal Procedure Act No 51 of 1977]. It may, however, become more difficult to perform this function independently as required by the Constitution when one is not aware of the objective criteria required for an assignment as a Military Judge. It would seem that different criteria may be used to determine who is assigned or not assigned as a Military Judge. One year, it is court hours, another year, it is that you must be in possession of a secret security clearance and unfortunately there appears to be no semblance of transparency in respect of the recommendation and/or appointment process to be considered as a fit and proper person to serve as a Military Judge. ${ }^{74}$

Although the above obiter remarks may attract a variety of views by those within the military or the military justice system for various reasons, the fact that they were expressed in this manner by a military judge in a court judgment illustrates unquestionably the nature of challenges faced by military judges in relation to judicial independence beyond the question of financial security raised in this article.

${ }^{74}$ State v Corporal Mabula Case No OPS 83 (14/15), Staff Sergeant Mokoena Case No OPS 22 (16/17) (2016) Court of Military Judge (Operations Support Legsato, Pretoria) para 12 (on file with the author). Lack of security of tenure will not be expanded on in this article because this author has already addressed this issue in previous published research already referred to elsewhere in this article. 
Can military judges be reasonably perceived as independent as things stand? Do military judges appear independent to a reasonable, well-informed, thoughtful and objective observer? It is my considered opinion that the answer is negative because a well-informed, thoughtful and objective observer will not perceive military judges as independent because military judges lack security of tenure, and are not, in the opinion of this author, adequately remunerated thereby lacking basic financial security as well. Let alone the question of institutional independence of military courts, which was not the subject of the study reflected here. Absence of objective guarantees of judicial independence, such as the ones identified in this article, does not require further evidence for an observer to conclude whether a court is independent. This is the approach, which is followed by the courts (including the Constitutional Court) in assessing whether a particular judicial body is independent.

Inadequate remuneration opens up judges to influences such as corruption. ${ }^{75}$ It also affects their independence as individuals because the inadequacy of remuneration forces them to perform in a way that will get them to the next higher notch instead of focussing on administering justice as they see fit. I make this point because the advancement of military law officers (military judges included) to the next salary notch is dependent on their performance or promotion, which are decided based on certain expectations. Military judges can hardly be perceived to be independent in such conditions.

It is suggested that the salaries of military judges should mirror those of magistrates. This means that, in line with the analysis of Tables $\mathrm{C}$ and $\mathrm{D}$, salaries of military judges (CMJ) would reflect those of magistrates presiding over district magistrates' courts, while those of senior military judges would mirror those of regional magistrates' courts. ${ }^{76}$ The disparity between military judges at the lower levels and magistrates is significant, at least according to the figures considered in this article. The suggested level of remuneration would help ensure that military judges are financially secure, and that more outstanding officers are attracted and retained.

Affordability is unlikely to be a big issue given that the size of the military judiciary is very small. As at 31 March 2004, there were only 19 full-time military

\footnotetext{
${ }^{75}$ However, to date, the author is not aware of a single case of corruption involving military judges.

${ }^{76}$ It would be interesting to compare the earnings of individual senior military judges and their counterparts in the regional magistrates' courts. Unfortunately, such information is not publicly available.
} 
judges, four of whom were senior military judges. ${ }^{77}$ This number has hardly grown as there are now (i.e. 2017) only 20 military judges, five of whom are senior military judges. The cost of salaries of military judges is negligible when compared with the number of magistrates in South Africa. As at 31 March 2016, there were 2 305 approved posts for magistrates. ${ }^{78}$ Of these, 1893 were filled. ${ }^{79}$ Certainly, South Africa cannot fail to provide financial security to its military judges even if the matter is viewed from an unfavourable economic conditions perspective.

\section{Conclusion}

Judicial independence of military judges is essential in ensuring a fair and credible military justice system. Current arrangements regarding remuneration of military judges do not provide adequate financial security for military judges. Specifically, the remuneration of military judges is inadequate compared to their civilian counterparts (magistrates) who discharge similar judicial functions albeit in a different context. In South Africa, there are no special measures to guarantee the remuneration of military judges. There is an emerging trend among some countries on the cutting edge of military justice to establish special measures to deal with financial security of military judges. Military judges are increasingly and rightfully receiving special attention. Achieving an acceptable degree of judicial independence of any court of law requires political will and a fair level of commitment of resources. It is hoped that government will financially grant military judges the necessary recognition befitting judicial officers as it does in respect of all civilian judicial officers.

\footnotetext{
- Associate Professor and Head of Department, Criminal and Procedural Law, Nelson Mandela University, aifheli.tshivhase@mandela.ac.za; aetshivhase@ gmail.com. The author has touched on this topic in previous published research but not in a detailed and systematic manner. See Tshivhase, AE 'Transformation of Military Courts' (2009) 24 SAPR/PL 450 at 470-4. The author is indebted to the anonymous reviewers.
}

\footnotetext{
${ }^{77}$ Presentation of the Military Legal Services Division (31 March 2004), available at www.pmg.org.za/docs/2004/appendices/040907services.ppt.

${ }^{78}$ Department of Justice and Constitutional Development, Annual Report (2015/2016) at 252 ${ }^{79}$ Ibid. http://www.justice.gov.za/reportfiles/anr2015-16.pdf.
} 